\title{
The Importance of Sodium/lodide Symporter (NIS) for Thyroid Cancer Management
}

\section{revisão}

\author{
Denise P. CARVALHO \\ ANDREA C.F. FERREIRA
}

Laboratório de Fisiologia Endócrina, Instituto de Biofísica Carlos Chagas Filho, Universidade Federal do Rio de Janeiro, RJ.

Recebido em 13/02/07 Aceito em 17/02/07

\begin{abstract}
The thyroid gland has the ability to uptake and concentrate iodide, which is a fundamental step in thyroid hormone biosynthesis. Radioiodine has been used as a diagnostic and therapeutic tool for several years. However, the studies related to the mechanisms of iodide transport were only possible after the cloning of the gene that encodes the sodium/iodide symporter (NIS). The studies about the regulation of NIS expression and the possibility of gene therapy with the aim of transferring NIS gene to cells that normally do not express the symporter have also become possible. In the majority of hypofunctioning thyroid nodules, both benign and malignant, NIS gene expression is maintained, but NIS protein is retained in the intracellular compartment. The expression of NIS in non-thyroid tumoral cells in vivo has been possible through the transfer of NIS gene under the control of tissue-specific promoters. Apart from its therapeutic use, NIS has also been used for the localization of metastases by scintigraphy or PET-scan with ${ }^{124}$ I. In conclusion, NIS gene cloning led to an important development in the field of thyroid pathophysiology, and has also been fundamental to extend the use of radioiodine for the management of non-thyroid tumors. (Arq Bras Endocrinol Metab 2007;51/5:672-682)
\end{abstract}

Keywords: Thyroid; NIS; Cancer; Radioiodine; lodide uptake; Gene transfer

\section{RESUMO}

\section{A Importância do Co-Transportador de Sódio/lodeto (NIS) no Manuseio do Câncer de Tireóide.}

A glândula tireóide tem capacidade de captar e concentrar iodeto, etapa fundamental na biossíntese dos hormônios tireóideos. O uso de iodo radioativo para fins de diagnóstico e terapia das doenças da tireóide vem sendo feito há muitos anos. Entretanto, somente após a clonagem do gene que codifica o cotransportador de sódio/iodeto (NIS) houve aumento significativo dos estudos relacionados ao mecanismo de transporte de iodeto. Os estudos sobre a regulação da expressão do NIS e a possibilidade de terapia gênica visando à transferência do gene NIS para células que normalmente não expressam esse transportador, foram também viabilizados. $\mathrm{Na}$ maior parte dos nódulos tireóideos hipofuncionantes, tanto benignos quanto malignos, a expressão do gene do NIS está presente, mas a proteína NIS fica retida no compartimento intracelular. A transferência do gene usando-se promotores tecido-específicos possibilitou a expressão do NIS em células tumorais não-tireóideas in vivo. Além do seu uso terapêutico, o NIS também vem sendo usado para a localização de metástases tumorais através da cintilografia ou do PET-scan usando-se ${ }^{124} \mathrm{I}$. Em conclusão, a clonagem do NIS possibilitou enorme avanço na área de fisiopatologia tireóidea e foi também fundamental para estender o uso do radioiodo para tumores não tireóideos. (Arq Bras Endocrinol Metab 2007;51/5:672-682)

Descritores: Tireóide; NIS; Câncer; Radioiodo; Captação de iodo; Transferência de gene 
$\mathrm{T}$ HE ABILITY OF THE THYROID gland to concentrate iodide by a factor of 20 to 40 in respect to the plasma compartment has first been recognized at the end of the $19^{\text {th }}$ century by Baumann (1). Only about 50 years later (1942), the use of radioiodine with diagnostic and therapeutic purposes has started, taking advantage of this characteristic of the thyroid gland. Another great advance in the field corresponds to the subsequent finding that iodine in excess blocks thyroid hormone biosynthesis and secretion (2). Based on these previous reports, radioiodine and saturated iodine solutions have long been used for the diagnosis and treatment of benign and malignant thyroid diseases, as well as the control of thyrotoxicosis $(3,4)$. However, the molecular nature and characteristics of the iodide transporter was poorly defined until 1996, when a breakthrough on the knowledge of thyroid pathophysiology occurred after the cloning of the gene that encodes the protein responsible for the transport of iodide into cells $(5,6)$.

The transport of iodide is a fundamental step in thyroid hormone biosynthesis and occurs through the $\mathrm{Na}^{+} / \mathrm{I}^{-}$symporter (NIS), an integral plasma membrane glycoprotein localized in the basolateral membrane of thyrocytes. NIS couples the inward transport of two $\mathrm{Na}^{+}$ ions, which occurs in favor of its electrochemical gradient, to the simultaneous inward translocation of one $\mathrm{I}^{-}$ion against its electrochemical gradient (7). After influx into thyrocytes, iodide is then translocated from the cytoplasm across the apical plasma membrane towards the follicular lumen, in a process called $\mathrm{I}^{-}$efflux that is mediated by a protein called pendrin $\left(\mathrm{a} \mathrm{Cl}^{-} / \mathrm{I}^{-}\right.$transporter $)(8)$, which is the product of the gene mutated in patients with Pendred's syndrome. More recently, another ion channel present in the apical membrane has been reported to be involved in the efflux of iodide from the follicular cell, the ClC5 chloride channel (9).

Differently from other tissues that are able to take up iodide from the circulation, the thyroid gland accumulates iodine for a prolonged period of time. This is the result of thyroid microscopic features and the prompt oxidation and organification of iodine into selected tyrosyl residues of thyroglobulin $(\mathrm{Tg})$, a reaction catalyzed by thyroperoxidase (TPO) in the presence of hydrogen peroxide generated by thyroid dual oxidase $(\mathrm{DuOx})(10)$.

The role of NIS protein in thyroid hormone biosynthesis has been unequivocally confirmed after the cloning of NIS gene and the description of mutations in patients with dyshormonogenetic goiters, together with the functional studies of the mutated proteins (11). The significance of NIS expression in the thyroid becomes even more apparent when one considers that iodine is scarce in the environment. Endemic goiter and cretinism are caused primarily by insufficient dietary supply of iodine and remain a major health problem in many parts of the world, affecting millions of people $(10,11)$.

The importance of NIS expression for the diagnosis and treatment of diseases has raised a series of questions regarding the mechanisms underlying not only the control of NIS expression, but also the regulation of its activity in the plasma membrane. In thyroid cells, iodide transport through NIS is stimulated by thyrotropin (TSH) and inhibited by the well-known classic competitive inhibitors thiocyanate $\left(\mathrm{SCN}^{-}\right)$and perchlorate $\left(\mathrm{ClO}_{4}^{-}\right)(5-7,11-13)$. TSH stimulates thyroid function via the activation of adenylate cyclase, including NIS transcription and de novo synthesis, but it also plays a possible role in the post-transcriptional regulation of NIS. TSH action allows the proper targeting of NIS to the plasma membrane, since NIS is redistributed from the basolateral membrane to intracellular compartments in the absence of TSH, and thereby the ability of thyrocytes to transport iodide is decreased $(11,14)$. Besides TSH other factors can influence NIS expression, such as thyroid iodine content, insulin, insulin-like growth factor, transforming growth factor (TGF) $\beta 1$, tumor necrosis factor (TNF) $\alpha$, interferon $\gamma$, interleukin (IL)$1 \alpha$, IL-1 $\beta$, IL-6 $(11,13,15)$.

NIS is not a thyroid-specific protein since its expression has been detected in extrathyroidal tissues, such as lactating mammary gland, gastric mucosa, salivary and lacrimal glands, choroid plexus, skin, placenta, and thymus, among other tissues. In these non-thyroidal tissues NIS gene expression is under the control of different mechanisms, the majority of which have not been identified yet.

In addition to its key role in thyroid pathophysiology, NIS-mediated iodide accumulation within other cell types could be used for diagnostic procedures and treatment of malignant diseases in other tissues. As a result, NIS gene transfer is being used to express functionally active NIS in other cell types, a strategy that could extend the application of radioiodine to non-thyroidal cancers (16). The main goal of this article is to review NIS molecular characteristics, the regulation of its expression and functionality at the plasma membrane, and finally to give insights into the new perspectives for its use as a diagnostic and therapeutic tool.

\section{MOLECULAR CHARACTERIZATION OF NIS}

NIS belongs to the sodium/solute symporter family (SSF, according to the transporter classification sys- 
tem) (17) or solute carrier family 5 (SLC5A, according to the Online Mendelian Inheritance in Man classification, OMIM). These transporters have the common feature of depending on the gradient of sodium as the driving force for ion transport across membranes. The rat and human (h) NIS cDNAs encode proteins composed of 618- and a 643-amino acid, respectively $(5,6,18)$. hNIS exhibits an $84 \%$ amino acid identity and $93 \%$ similarity to rat NIS. The human NIS gene maps to 19pl3.2-pl2 (18) and contains 14 introns and 15 exons. The rat NIS gene is markedly smaller in size compared with the human one, although the number of exons is the same and the mRNA sizes are similar. The current NIS secondary structure model depicts NIS as a protein with 13 transmembrane segments (TMS) (figure 1), the amino terminus facing the extracellular milieu, and the carboxy terminus facing the cytosol; the location of both termini has been confirmed experimentally $(19,20)$.

NIS-mediated $\mathrm{I}^{-}$transport is driven by the transmembrane $\mathrm{Na}^{+}$gradient that is actively generated by the ouabain sensitive $\mathrm{Na}^{+} / \mathrm{K}^{+}$-ATPase pump, since NIS couples the inward transport of two $\mathrm{Na}^{+}$ions to the simultaneous translocation of one $\mathrm{I}^{-}$ion. NIS thus functions as an electrogenic transporter, accumulating positive charge inside the cell.

Although the mature NIS is a glycoprotein with at least three Asn-glycosylation sites (figure 1), the lack of N-linked glycosylation of the molecule does not impair its function, stability or targeting to the cellular membrane. NIS is synthesized as a precursor of approximately $56 \mathrm{kDa}$ and the mature glycolsylated protein has $87 \mathrm{kDa}(11)$.

\section{$\mathrm{Na}^{+} / /-$SYMPORTER (NIS)}

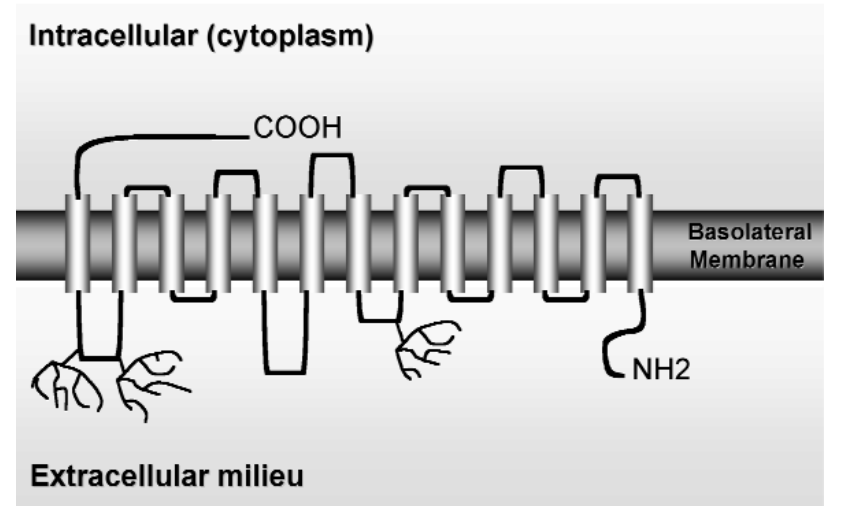

Figure 1. Current NIS secondary structure model.
Structure and function studies have demonstrated that a hydroxyl group at position 354 is essential for NIS function, in such a way that mutations in the Thr 354 leads to loss of NIS function. In several patients with congenital hypothyroidism due to a defect in thyroid iodide uptake the substitution of Thr to Pro at position 354 (T354P) has been found (21). This amino acid substitution occurs in the transmembrane segment IX, where some other hydroxyl groups are present. In fact, the hydroxyl groups present in amino acids at positions Ser 353, Ser 356, and Thr 357 are also fundamental for NIS activity. Another mutation found in patients with congenital hypothyroidism and impaired iodide uptake is the substitution of Gly 395. The presence of an uncharged amino acid residue with a small side chain at position 395 is also necessary for NIS activity (22).

NIS is able to transport other anions, although it has a higher selectivity for iodide. Thiocyanate competes with iodide for the transporter and thus decreases iodide accumulation; however, perchlorate, which is 10-100 times more potent than thiocyanate as a NIS inhibitor, does not seem to be a substrate and is not translocated by NIS (11).

\section{REGULATION OF EXPRESSION AND FUNCTION IN THYROID CELLS}

\section{TSH and iodide}

TSH is required for the maintenance of differentiation and for the proliferation of thyroid follicular cells. Besides the induction of other thyroid specific differentiation markers, TSH stimulates NIS gene expression, and increases iodide uptake by thyrocytes $(14,23)$. The majority of TSH actions on the thyrocytes are mediated by the intracellular increase in cyclic adenosine 3',5'-monophosphate (cAMP) levels, which is secondary to adenylate cyclase activation. Both NIS expression and targeting to the plasma membrane are stimulated by TSH through the cAMP pathway (table 1), however the exact mechanism by which NIS gene promoter is regulated by cAMP has not been fully understood. Rat NIS promoter has been extensively studied so far and two important proximal regions described are a binding site for Titfl (TTFl) and a TSH responsive element, where a putative transcription factor NTF-1 (NIS TSH responsive factor-1) interacts. The NIS upstream promoter (NUE) contains two Pax 8 binding sites and a cAMP response element-like sequence binding proteins. NUE region is essential for full responsiveness to TSH (24). 
NIS half-life is long and also modulated by TSH. In the presence of TSH, NIS half-life is about 5 days whereas in the absence of TSH it decreases to 3 days (14).

Like other transporters, NIS protein seems to exist in at least two distinct sub cellular compartments: the plasma membrane and intracellular vesicles. The latter being a pool of NIS protein that could be rapidly mobilized by TSH and other still undefined mechanisms $(14,23,25)$. Recently, we have demonstrated the rapid modulation of NIS function at the plasma membrane using a new methodological approach in vivo (26): the precocious thyroid radioiodide uptake measurement (15 minutes after radioiodide administration). Some factors are determinants of iodine content in the thyroid gland: iodide uptake through NIS, iodide efflux and iodine organification at the apical membrane. The 15 min iodide uptake measurement is not influenced by the previous administration of methylmercaptoimidazole (MMI), a drug that inhibits organification. On the other hand, the $2 \mathrm{~h}$-iodide uptake is decreased by almost $90 \%$ when MMI is administered before iodide, showing that after $2 \mathrm{~h}$ of iodide administration the majority of iodide accumulated in the thyroid has already been organified. Thus, radioiodine content measured after 15 min of iodide administration can be an efficient evaluation of the basolateral transport of iodide through NIS, without the interference of iodide efflux and organification (26).

Animals treated with MMI for 21 days are hypothyroid, have high serum TSH and increased NIS function. When MMI is removed 2 days before sacri- fice, serum TSH is still high and NIS activity significantly decreases. This rapid decrease in NIS activity is probably related to NIS redistribution into the thyrocyte, since this protein has a long half-life of $3-5$ days (14). The lower NIS activity in the presence of still elevated serum TSH indicates that organified iodine might be a potent NIS regulator, since 2 days after MMI withdrawal TPO has resumed its activity, leading to the production of an iodinated compound (IX), which might be responsible for the inhibition of iodide transport through the basolateral membrane of the thyrocyte. Serum $\mathrm{T}_{4}$ also began to rise 2 days after MMI withdrawal, and reached normal values after 5 days without MMI, confirming the early TPO activity resumption after MMI withdrawal (26).

Exposure of thyroid cells to high concentrations of iodine in vitro and in vivo results in the reduction of iodide transport and its organification into proteins, the so-called Wolff-Chaikoff effect (2). The regulation of thyroid function by iodine (auto-regulation) is transient, since thyroid cells are able to escape from the effects of iodine after some days of exposure (27). The mechanisms involved in the escape from the Wolff-Chaikoff effect are not known, but the cloning of NIS allowed new insights into this important issue related to thyroid gland physiology. Eng et al. (28) showed that a significant decrease in the levels of NIS mRNA and protein were detected in rat thyroids 1 and 6 days after an excess of iodine (table 1), suggesting that decreased NIS expression could be implicated in the escape from the

Table 1. Factors that regulate NIS expression and/or function.

\begin{tabular}{|c|c|}
\hline FACTOR & EFFECT \\
\hline TSH & $\begin{array}{l}\text { Stimulates NIS gene expression, and increases iodide uptake } \\
\text { by thyrocytes in culture and thyroid gland }\end{array}$ \\
\hline lodide & $\begin{array}{l}\text { Decreases the levels of NIS mRNA and protein, and reduces } \\
\text { NIS function at the plasma membrane. These effects seem to } \\
\text { depend on the production of organified iodine (IX) }\end{array}$ \\
\hline Estrogen & $\begin{array}{l}\text { Reduces the sodium-iodide symporter gene expression and } \\
\text { the transport of iodide into FRTL- } 5 \text { thyroid cell lines. In } \\
\text { ovariectomized rats treated with estradiol, NIS function increases }\end{array}$ \\
\hline Retinoic acid & $\begin{array}{l}\text { Different studies show that RA administration re-stimulates } \\
\text { iodine uptake in about } 20-50 \% \text { of patients with radioiodine } \\
\text { non-responsive thyroid carcinoma }\end{array}$ \\
\hline Cytokines & Decrease NIS expression \\
\hline $\begin{array}{l}\text { Histone deacetylase } \\
\text { inhibitors }\end{array}$ & $\begin{array}{l}\text { Treatment of thyroid cancer cell lines with histone deacetylase } \\
\text { inhibitors increases NIS expression as well as iodide uptake }\end{array}$ \\
\hline Pax8 expression & $\begin{array}{l}\text { This thyroid transcription factor is often reduced in thyroid tumors. } \\
\text { The re-expression of Pax } 8 \text { seems to be associated with the recovery } \\
\text { of the NIS mRNA expression in rat thyroid cell line }\end{array}$ \\
\hline Thyroglobulin & $\begin{array}{l}\text { Thyroglobulin (TG) accumulated in the follicular lumen might } \\
\text { reduce NIS mRNA levels secondary to decreased Pax-8 } \\
\text { mRNA and protein levels }\end{array}$ \\
\hline
\end{tabular}


Wolff-Chaikoff effect. More recently, we showed that iodine excess also interferes with NIS function at the plasma membrane, since sodium iodide (NaI) administration for 6 days led to a significant reduction in NIS activity in vivo (26). NaI treatment is unable to reduce radioiodide transport when TPO activity was concomitantly inhibited by MMI administration, showing that NIS function is reduced by iodide only when TPO activity is present. These results support the idea that organified iodine (IX) rather than iodide itself is responsible for the inhibition of the basolateral transport of $\mathrm{I}^{-}$, as previously suggested (29). The iodinated compounds that are candidates for iodine organification blockade are iodolipids (iodohexadecanal and iodolactones) $(30,31)$.

In conclusion, NIS function at the plasma membrane of thyrocytes depends tightly on TSH although intracellular organified iodine is also an important NIS modulator. Based on the fact that not only NIS expression but also its targeting to the plasma membrane are dependent on TSH, a decreased cellular response to TSH when organified iodine content increases might explain the decreased iodide uptake even when serum TSH is still high.

These data reinforces the importance of a low iodine diet regimen prior to radioiodine administration to patients with a diagnostic or therapeutic purpose for thyroid disease management.

\section{Estrogen}

The prevalence of thyroid diseases is higher in women than in men, and in the postmenopausal period a further increase is detected $(32,33)$. Some previous reports indicate that estradiol might regulate thyroid function through a direct action on thyrocytes (34), apart from a possible effect on TSH secretion (35-38). The administration of estradiol to ovariectomized and hypophysectomized rats leads to a higher thyroid radioiodide uptake $(32,39)$, which supports the hypothesis of a direct effect of estrogen on the thyroid. More recently, the presence of estrogen receptors has been demonstrated in both human and rat thyroid glands $(40,41)$.

Although estradiol (table 1 ) seems to stimulate thyroid iodide uptake in vivo, a recent report has shown that estradiol reduces the sodium-iodide symporter gene expression and the transport of iodide into FRTL-5 thyroid cell line (34). In order to address the question of whether NIS function could be affected by estrogen in vivo, we have shown that the short-term radioiodide uptake is significantly increased in ovariectomized rats treated with estradiol for 10 days. Besides, we also evidenced a strong increase in TPO activity in the OVX group that received the higher dose of estradiol (14 ug estradiol benzoate/100 g body weight). Altogether, these data suggest that estrogen stimulates both NIS and TPO activities in the thyroid of ovariectomized rats. These effects appear not to be mediated by serum TSH, which was unchanged by estrogen, and could probably occur through a direct action of estradiol on these two essential steps of thyroid hormone synthesis (42).

Radioiodide uptake was also increased in prepubertal animals that received the higher dose of estradiol, whereas TPO activity was unchanged in prepubertal rats treated with estradiol (42). The mechanism underlying the specific action of estradiol on thyroid NIS activity in prepubertal rats remains to be elucidated. In adult intact animals, radioiodide uptake remained unchanged by estradiol treatment, while both doses of estradiol increased TPO activity. Our findings support the idea that the regulation of TPO and NIS activities by estradiol depends on the gonadal status and/or the age of the female rat. It is tempting to speculate whether these differences might be related to different estrogen receptors population in the thyroid gland at these different stages of development and in FRTL-5 cells.

\section{Retinoic acid}

Retinoic acids (RA) are biologically active metabolites of vitamin A, which regulate growth and differentiation of many cell types by binding to specific nuclear receptors (43). Recent studies with RAs have shown that these drugs can induce in vitro re-differentiation of thyroid carcinoma cell lines, as suggested by increased expression of some thyroid specific proteins (44-47), and by the increment of cellular radioiodine uptake (table 1) (48). In different studies, RA administration re-stimulated iodide uptake in about $20-50 \%$ of patients with advanced thyroid carcinoma (49-56).

The exact mechanisms by which RAs could reinduce NIS expression in some thyroid tumors have not been defined yet.

\section{Other factors}

Interferons (IFNs) have been used to treat patients with chronic viral hepatitis, malignant disorders, and multiple sclerosis. IFN therapy has also been associated with a relatively high risk of developing thyroid dysfunction (57-59), and recently IFN was shown to decrease thyroid NIS expression (60).

Other cytokines have also been shown to play a role in the modulation of NIS function in thyroid cells. Cytokines that affect thyroid function and growth and cause immunological changes in the gland are produced by both infiltrating inflammatory cells and the thyroid fol- 
licular cells themselves, although the latter only occurs in autoimmune thyroid disease (61). The thyroidal effects of cytokines have mostly been examined in FRTL- 5 cells kept in TSH-free medium, to which TSH and cytokines were then added simultaneously (62). The cytokines investigated include TNF- $\alpha$, TNF- $\beta$, interferon- $\gamma$ (IFN$\gamma)$, IL-1 $\alpha$, IL- $1 \beta$, IL- 6 , and TGF- $\beta 1$, all of which exerted an inhibitory effect on thyroid function, including decreased NIS expression and iodide uptake.

Histone acetylation involves the reversible transfer of the acetyl group of acetylcoenzyme A to the amino group of lysine residues at histone proteins. This reaction is catalyzed by histone acetyltransferases (HATs) and can be reversed by histone deacetylases (HDACs) (63-65). Therefore, HAT and HDAC activities determine the acetylation levels of histones, and thus gene transcription since acetylated histones lead to a relaxation of DNA strands, allows the access of protein transcription machinery and increases DNA transcription. Several compounds induce histone hyperacetylation by reducing the rate of histone deacetylation through the inhibition of HDAC (66). Several reports have shown that treatment of thyroid cancer cell lines with histone deacetylases inhibitors increases NIS expression as well as iodide uptake (67-72).

The thyroid-specific transcription factor Pax 8 , a paired domain protein, is able to regulate, in normal thyroid cells, the expression of many thyroid specific proteins and is often reduced in thyroid tumors, especially in the less differentiated ones (73-76). Reexpression of Pax8 is associated with the recovery of NIS, as well as TPO and Tg mRNA expressions in a rat thyroid cell line (77). Presta et al. (78) showed that stably transfection of Pax8 into thyroid tumor cells recovers their iodine uptake ability.

Suzuki et al. (79) have shown that thyroglobulin (TG) accumulated in the follicular lumen is a potent suppressor of NIS mRNA levels, in addition to decreasing mRNA levels of TG itself, TPO, and TSH receptor (TSHR). Follicular TG seems to decrease TG, TPO and NIS expression secondary to a decrease in Pax- 8 mRNA and protein levels. Although these data are very interesting and intriguing, the possible auto-regulatory effect of TG needs further confirmation and definition of its physiological importance.

\section{REGULATION OF EXPRESSION AND FUNCTION IN BREAST CANCER (MCF-7) CELLS}

Differently from its regulation in thyroid cells, NIS expression in MCF-7 cells is down regulated by cAMP increase. However, all-trans-retinoic acid modestly increases NIS expression, an effect that is markedly potentiated by hydrocortisone and purinergic signaling (80).

These recent findings show unequivocally that the regulation of NIS expression is cell-type specific. Thus, not only the induction of NIS expression by a tumor is important for its use as a therapeutical tool, but also the knowledge about its regulation in each cell type will be of great importance.

\section{NIS AND THYROID DISEASE}

\section{Congenital hypothyroidism}

Thyroid iodide uptake defects lead to decreased thyroid hormone biosynthesis, increased serum TSH and goiter. Congenital hypothyroidism due to impaired iodide uptake has long been described in the literature; however, NIS mutations were recognized only after the cloning of NIS cDNA, and correspond to point mutations [G93R, Q267E, C272X, T354P, Y531X, G543E, G395R, V59E or frameshift (515X)]. Functional studies have already been done for some mutated NIS and have confirmed the following changes in NIS molecular characteristics: loss of function of the protein (T354P, G395R), partial activity (Q267E) or impaired targeting of the protein to the plasma membrane (G543E) (81,82).

\section{Benign thyroid lesions}

Benign hypofunctioning thyroid lesions of follicular origin, as well as malignant ones, show a decrease of iodide uptake activity. Either increased or decreased hNIS expression in benign lesions has been reported. Probably these discordant findings are related to different methodological approaches. It is now believed that NIS gene expression can be normal or even high in some lesions (about $50 \%$ ), however mature NIS protein expression is absent in all benign hypofunctioning lesions. hNIS immunoreactive species are identified mainly intracellularly (figure 2 ), and the expressed NIS protein has a low-molecular mass, suggesting a post-translational defect (83).

In hyperfunctioning thyroid nodules and diffuse toxic goiters, NIS protein is highly expressed and functional, thus allowing the use of radioactive iodide for the destruction of these goiters and the management of hyperthyroidism (84).

\section{Differentiated thyroid cancer}

In the case of DTC, the detection of cancer relapse by whole body scanning and treatment of cervical remnant, locoregional and distant metastasis with radioiodine are possible due to the ability of tumor cells to 


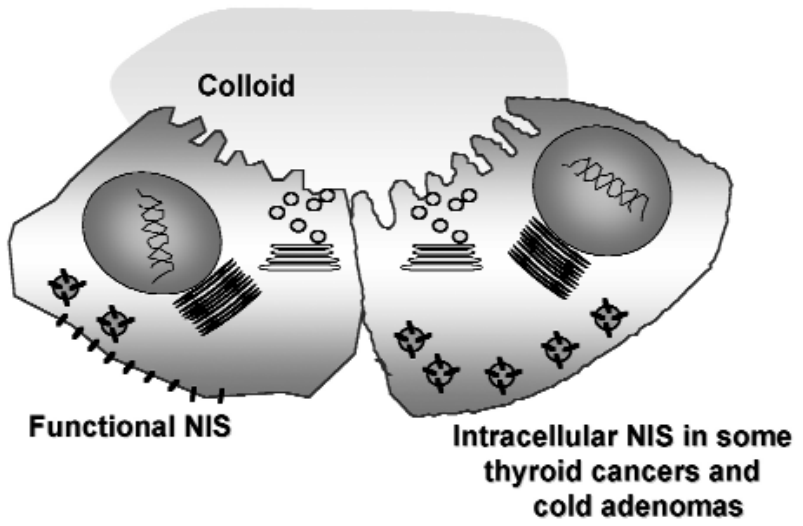

Figure 2. NIS localization in normal and tumoral thyroid cells.

accumulate iodine. The higher tumor recurrence rate in patients treated only with surgery and TSH suppression than in those who also received radioiodine therapy shows the importance of thyroid remnant ablation by radioiodine (85). However, the effectiveness of radioiodine therapy depends on the effective radiation dose delivered to the tumor tissue, which depends on the iodine concentrating ability of the cells.

Although DTC retain most of the biochemical properties that are specific of normal follicular cells, a variety of abnormalities have been demonstrated. For example, malignant tumors show up as hypofunctioning areas on thyroid scintigraphy, indicating that their iodine uptake and/or accumulation are impaired.

Ryu et al. (86) reported lower expression of NIS mRNA in samples of thyroid carcinoma compared to normal tissues. Other studies using quantitative RT-PCR or immunohistochemistry also showed that NIS levels in carcinomas were decreased $(87,88)$.

Although reduced NIS expression might be responsible for the thyroid inability to concentrate iodine, immunohistochemistry studies demonstrated that NIS is indeed overexpressed in some thyroid cancer samples. In fact, recent data showed that NIS localization is mostly intracellular in some tumors (figure 2), suggesting that impaired targeting of NIS to the plasma membrane could explain the decreased iodide uptake ability $(12,25,89)$.

During tumor progression, up to $30 \%$ of patients with persistent/metastatic thyroid carcinoma show cellular de-differentiation, characterized by more aggressive growth, loss of iodide uptake ability and other markers of thyroid cell differentiation. These patients with de-differentiated thyroid carcinoma represent a therapeutic challenge, since treatment options are limited, and usually not efficient.
The crucial role of radioiodine therapy for the evolution of thyroid carcinomas stimulated the search for drugs that could enhance functional NIS expression in tumors and thus iodine accumulation, such as retinoic acid, histone deacetylase inhibitors and blockers of methyltransferase, as mentioned above.

\section{NIS EXPRESSION IN NON-THYROID TISSUES}

Apart from the thyroid gland, NIS is normally expressed in salivary glands, lactating mammary gland, lacrimal glands, stomach, choroid plexus, ciliary body of the eye, skin, placenta, and thymus (11).

Nonthyroidal transport of iodide share similar characteristics as those of the thyroid gland: the transport of iodide is inhibited by perchlorate and thiocyanate, and the concentration gradient generated by the transport is of similar magnitude.

Several studies have localized NIS in the basolateral membrane of exocrine glands and indicate that NIS might be involved in the transport of iodide from the serum to the secreted fluids of these glands. Besides the maternal-newborn or -fetal transfer of iodide by mammary glands and placenta, the iodide in secretory fluids could be transformed in hypoiodide and function as antimicrobial agent (11).

\section{NIS GENE TRANSFER FOR CANCER MANAGEMENT}

In order to extend the use of radioiodine therapy to non-thyroid cancers, the transfer of NIS gene to cancer cell lines have already been tested (90). NIS gene transfer has been effective and iodide uptake was successful in several types of human cancer cell lines, like cervix cancer, breast cancer, glioma, hepatoma, prostate carcinoma, non-small cells lung cancer, follicular thyroid carcinoma, ovarian cancer, pancreatic cancer, melanoma, and myeloma $(11,91,92)$.

Not only iodide uptake is necessary, but also its retention is relevant to enable its cytotoxic effects to occur. The radiation dose necessary to exert a therapeutic effect is not achieved due to the rapid efflux of radioiodide from the cells. To try to overcome this problem, some drugs that decrease iodide efflux have been tested (93). Also, the efficiency of NIS transfer has been improved with the use of modified vectors $(94,95)$ and higher viral doses, however this approach increases the toxicity of gene therapy approach. Thyroid gland not only concentrates iodide but also retains it for several 
days because of its iodide organification ability. However, the importance of iodide organification for its retention in thyroid tumors is questionable.

The selective targeting of NIS to malignant cells can be achieved by using tissue-specific promoters that drive NIS gene expression. Xenograft tumors in nude mice have been used to test the effectiveness of in vitro NIS gene transfer into prostate tumor cells. The size of the xenograft tumors expressing NIS was significantly reduced after the administration of a therapeutic dose of radioiodide (95). Adenovirus-mediated in vivo NIS gene transfer has also been effective for increasing iodide uptake in prostate cancer xenografts in nude mice, indicating that in vivo gene transfer into different types of tumors might indeed function in the future. In these animals that received the injection of adenovirus vector carrying NIS gene linked to the cytomegalovirus promoter, the volume of prostate tumor xenografts was significantly reduced by radioiodine administration (96). These findings indicate that NIS gene delivery can lead to sufficient NIS activity for radioiodide therapeutic use and also that iodide organification is not a fundamental step for radioiodine effectiveness to occur. hNIS gene transfer has also been tested using the calcitonin-promoter to target NIS gene expression to medullary thyroid cancer cells (97). After NIS-gene transfer, these cells were able express functional NIS and to significantly uptake iodide. Altogether, these results show that NIS gene transfer corresponds to a promising approach that leads to a significant increase in the iodide uptake ability by different tumor cell types.

Apart from the use of NIS gene transfer with therapeutic purposes, the uptake of radioiodide allows the localization of metastasis and cancer recurrence. Thus, the use of NIS for non-invasive imaging has been recently tested. Positron-emission tomography (PET) can be used in NIS transduced tumors using ${ }^{124} \mathrm{I}$, an isotope of iodine that emits positrons. PET scan permits a high-resolution imaging and precise anatomical localization of tumors (98).

\section{OTHER RADIOACTIVE ISOTOPES TRANSPORTED BY NIS}

Technetium is transported by NIS and has been used for thyroid scintigraphic imaging (99). Rhenium is a chemical analog of technetium that corresponds to a beta emitting radionuclide with a half-life of 16.7 hours. Rhenium could be effective over a higher tissue range $(23-32 \mathrm{~mm})$, being effective also for treatment of large tumors $(100,101)$. Further studies are needed in order to better define whether the use of rhenium can be more effective than that of ${ }^{131} \mathrm{I}$.

Astatine is an alfa-emitting radiohalide with a high linear energy, however its tissue range is short and its availability is scarce (102).

\section{ACKNOWLEDGEMENTS}

This work was supported by grants from Fundação Carlos Chagas Filho de Amparo à Pesquisa do Estado do Rio de Janeiro (FAPERJ), Conselho Nacional de Desenvolvimento Científico e Tecnológico (CNPq) and Coordenação de Aperfeiçoamento de Pessoal de Nível Superior (CAPES).

\section{REFERENCES}

1. Baumann E. Uber den Jodgehalt der Schilddrüsen Von Menchen und Tieren. Hoppe Seylers Z Physiol Chem 1896;22:1-17.

2. Wolff J, Chaikoff IL. Plasma inorganic iodide as a homeostatic regulator of thyroid function. J Biol Chem 1948;174:555-64.

3. Cardoso LC, Martins DC, Campos DV, Santos LM, Correa da Costa VM, Rosenthal D, et al. Effect of iodine or iopanoic acid on thyroid $\mathrm{Ca}^{2+} / \mathrm{NADPH}$-dependent $\mathrm{H}_{2} \mathrm{O}_{2}$-generating activity and thyroperoxidase in toxic diffuse goiters. Eur J Endocrinol 2002;147(3):293-8.

4. Heufelder AE, Morgenthaler N, Schipper ML, Joba W. Sodium iodide symporter-based strategies for diagnosis and treatment of thyroidal and nonthyroidal malignancies. Thyroid 2001;11:839-47.

5. Dai G, Levy O, Carrasco N. Cloning and characterization of the thyroid iodide transporter. Nature 1996;379:485-60.

6. Smanik PA, Liu Q, Furminger TL, Ryu K, Xing S, Mazzaferri $E L$, et al. Cloning of the human sodium iodide symporter. Biochem Biophys Res Commun 1996;226:339-45.

7. Eskandari S, Loo DDF, Dai G, Levy O, Wright EM, Carrasco N. Thyroid $\mathrm{Na}^{+} / \mathrm{I}^{-}$Symporter - mechanism, stoichiometry, and specificity. J Biol Chem 1997;272:27230-8.

8. Scott DA, Wang R, Kreman TM, Sheffield VC, Karniski LP. The Pendred syndrome gene encodes a chloride-iodide transport protein. Nat Genet 1999;21(4):440-3.

9. van den Hove MF, Croizet-Berger K, Jouret F, Guggino SE, Guggino WB, Devuyst O, et al. The loss of the chloride channel, CIC5 , delays apical iodide efflux and induces a euthyroid goiter in the mouse thyroid gland. Endocrinology 2006;147:1287-96.

10. Taurog A. Hormone synthesis: Thyroid iodine metabolism. In: Braverman LE, Utiger RD (eds). The Thyroid: A Fundamental and Clinical Text. $8^{\text {th }}$ ed. Philadelphia: Lippincott Williams \& Wilkins, 2000. pp. 61-85.

11. Dohan O, De la Vieja A, Paroder V, Riedel C, Artani M, Reed M, et al. The sodium/iodide symporter (NIS): characterization, regulation, and medical significance. Endocr Rev 2003;24:48-77.

12. Dohan O, Baloch Z, Banrevi Z, Livolsi V, Carrasco N. Rapid communication: predominant intracellular overexpression of the $\mathrm{Na}^{+} / /^{-}$symporter (NIS) in a large sampling of thyroid cancer cases. J Clin Endocrinol Metab 2001;86:2697-700.

13. Dohan O, Carrasco N. Advances in $\mathrm{Na}^{+} / /^{-}$symporter (NIS) research in the thyroid and beyond. Mol Cell Endocrinol 2003;213(1):59-70.

14. Riedel C, Levy O, Carrasco N. Post-transcriptional regulation of the sodium/iodide symporter by thyrotropin. J Biol Chem $2001 ; 276: 21458-63$. 
15. Riesco-Eizaguirre G, Santisteban P. A perspective view of sodium iodide symporter research and its clinical implications. Eur J Endocrinol 2006;155(4):495-512.

16. Spitzweg C, Morris JC. Approaches to gene therapy with sodium/iodide symporter. Exp Clin Endocrinol 2001:109:56-9.

17. Reizer J, Reizer A, Saier MH Jr. A functional superfamily of sodium/solute symporters. Biochim Biophys Acta 1994; 1197(2):133-66.

18. Smanik PA, Ryu KY, Theil KS, Mazzaferri EL, Jhiang SM. Expression, exon-intron organization, and chromosome mapping of the human sodium iodide symporter. Endocrinology 1997:138(8):3555-8.

19. Levy O, Dai G, Riedel C, Ginter CS, Paul EM, Lebowitz AN, et al. Characterization of the thyroid $\mathrm{Na}^{+} / \mathrm{I}^{-}$symporter with an anti-COOH terminus antibody. Proc Natl Acad Sci USA 1997:94:5568-73.

20. Levy O, De la Vieja A, Ginter CS, Riedel C, Dai G, Carrasco N. $\mathrm{N}$-linked glycosylation of the thyroid $\mathrm{Na}^{+} / \mathrm{I}^{-}$symporter (NIS). Implications for its secondary structure model. J Biol Chem 1998;273:22657-63.

21. Fujiwara H, Tatsumi K, Miki K, Harada T, Okada S, Nose O, et al. Recurrent T354P mutation of the $\mathrm{Na}^{+} / \mathrm{I}^{-}$symporter in patients with iodide transport defect. J Clin Endocrinol Metab 1998;83(8):2940-3.

22. Dohan O, Gavrielides MV, Ginter C, Amzel LM, Carrasco N. $\mathrm{Na}^{+} / /^{-}$symporter activity requires a small and uncharged amino acid residue at position 395. Mol Endocrinol 2002;16(8):1893-902

23. Kaminsky SM, Levy O, Salvador C, Dai G, Carrasco N. $\mathrm{Na}^{+} /^{-}$ symport activity is present in membrane vesicles from thyrotropin-deprived non- $\mathrm{I}^{-}$transporting cultured thyroid cells. Proc Natl Acad Sci USA 1994:91:3789-93.

24. Ohno M, Zannini M, Levy O, Carrasco N, di Lauro $R$. The paired-domain transcription factor $\mathrm{Pax} 8$ binds to the upstream enhancer of the rat sodium/iodide symporter gene and participates in both thyroid-specific and cyclic-AMPdependent transcription. Mol Cell Biol 1999;19(3):2051-60.

25. Tonacchera M, Viacava $P$, Agretti $P$, de Marco G, Perri A, di Cosmo $\mathrm{C}$, et al. Benign nonfunctioning thyroid adenomas are characterized by a defective targeting to cell membrane or a reduced expression of the sodium iodide symporter protein. J Clin Endocrinol Metab 2002;87:352-7.

26. Ferreira AC, Lima LP, Araújo RL, Muller G, Rocha RP, Rosenthal $D$, et al. Rapid regulation of thyroid sodium-iodide symporter activity by thyrotrophin and iodine. J Endocrinol 2005;184(1):69-76.

27. Braverman LE, Ingbar SH. Changes in thyroidal function during adaptation to large doses of iodide. J Clin Invest 1963;42:1216-31.

28. Eng PHK, Cardona GR, Fang SL, Previti M, Alex S, Carrasco N, et al. Escape from the acute Wolff-Chaikoff effect is associated with a decrease in thyroid sodium/iodide symporter messenger ribonucleic acid and protein. Endocrinology 1999:140:3404-10.

29. Grollman EF, Smolar A, Ommaya A, Tombaccini D, Santisteban P. lodine suppression of iodide uptake in FRTL-5 thyroid cells. Endocrinology 1986;118:2477-82.

30. Pisarev MA. Thyroid autoregulation. J Endocrinol Invest 1985;8(5):475-84.

31. Pereira A, Braekman JC, Dumont JE, Boeynaems JM. Identification of a major iodolipid from the horse thyroid gland as 2-iodohexadecanal. J Biol Chem 1990;265(28):17018-25.

32. Fukuda H, Greer M, Roberts L, Allen CE, Critcholow V, Wilson M. Nyctohemeral and sex-related variations in plasma thyrotropin, thyroxinne, and triiodotironine. Endocrinology 1975;97:1424-30.

33. Urban RJ. Neuroendocrinology of aging in the male and female. Endocrinol Metab Clin North Am 1992;21:921-31.

34. Furlanetto TW, Nguyen LQ, Jameson JL. Estrogen increases proliferation and down-regulates the sodium/iodide symporter gene in FRTL-5. Endocrinology 1999;140:5705-11.

35. Chen HJ, Walfish PG. Effects of age and ovarian function on the pituitary-thyroid system in female rats. J Endocrinol 1978;78:225-32.
36. Christianson D, Roti E, Vagenakis AG, Braverman LE. The sex-related difference in serum thyrotropin concentration is androgen mediated. Endocrinology 1981;108:529-35.

37. Fisher JS, D'Angelo SA. Stimulatory and inhibitory action of estrogen on TSH secretion. Endocrinology 1971;88:687-91.

38. Lisboa PC, Curty FH, Moreira RM, Pazos-Moura CC. Effects of estradiol benzoate on $5^{\prime}$ - iodotironine deiodinase activities in female rat anterior pituitary gland, liver and thyroid gland. Braz J Med Biol Res 1997:30:1479-84.

39. Boccabella AV, Alger EA. Influence of estradiol on thyroid: serum radioiodine concentration ratios of gonadectomized and hypophysectomized rats. Endocrinology 1964;74:680-8.

40. Hiasa Y, Kitahori Y, Yane K, Nishioka H, Nakahashi K, Konishi $\mathrm{N}$, et al. Establishment of estrogen receptor-positive transplantable rat thyroid tumor cell lines in vivo. Cancer Res 1993:53:4408-12.

41. Banu SK, Govindarajulu P, Aruldhas MM. Testosterone and estradiol up-regulate androgen and estrogen receptors in immature and adult rat thyroid glands in vivo. Steroids 2002;67:1007-14.

42. Lima LP, Barros IA, Lisboa PC, Araújo RL, Silva AC, Rosenthal $D$, et al. Estrogen effects on thyroid iodide uptake and thyroperoxidase activity in normal and ovariectomized rats. Steroids 2006;71(8):653-9.

43. Marcus M, Coulton AM. Fat-soluble vitamins A, K, E. In: Hadman JG, Limbird LE, Gilman AG (eds). Goodman and Gilmamn's The Pharmacologic Basis of Therapeutics. Mc Graw Hill, 2000. pp. 1773-92.

44. Kurebayashi J, Tanaka K, Otsuki T, Moriya T, Kunisue H, Uno $\mathrm{M}$, et al. All-trans-retinoic acid modulates expression levels of thyroglobulin and cytokines in a human poorly differentiated papillary thyroid carcinoma cell line, KTC-1. J Clin Endocrinol Metab. 2000;85:2889-96.

45. Schmutzler C, Winzer R, Maissner-Weigl J, Köhrle J. Retinoic acid increases sodium/iodide symporter mRNA levels in human thyroid cancer cell lines and suppresses expression of function symporter in nontransformed FRTL-5 rat thyroid cells. Biochem Biophys Res Commun 1997;240:832-8.

46. Schreck R, Schnieders F, Schmutzler C, Köhrle J. Retinoids stimulate type I iodothyronine $5^{\prime}$-deiodinase activity in human follicular thyroid carcinoma cell lines. J Clin Endocrinol Metab 1994;79:791-8.

47. Schmutzler C, Brtko J, Bienert K, Köhrle J. Effects of retinoids and role of retinoic receptor in human thyroid carcinomas and cell lines derived there from. Exp Clin Endocrinol Diabetes 1996;104(suppl 4):16-9.

48. Van Herle AJ, Agatep ML, Padua DN, Totanes TL, Canlapan DV, Van Herle HML, et al. Effects of 13-cis-retinoic acid on growth and differentiation of human follicular carcinoma cells (UCLA RO 82 W-1) in vitro. J Clin Endocrinol Metab 1990;71:755-63.

49. Simon D, Köhrle J, Schmutzler C, Mainz K, Reiners C, Röher HD. Redifferentiation therapy of differentiated thyroid carcinoma with retinoic acid: basics and first clinical results. Exp Clin Endocrinol Diabetes 1996;104(suppl 4):13-5.

50. Simon D, Koehrle J, Reiners C, Boerner AR, Schmutzler C, Mainz K, et al. Redifferentiation therapy with retinoids: therapeutic option for advanced follicular and papillary thyroid carcinoma. World J Surg 1998;22:569-74.

51. Grünwald F, Menzel C, Bender H, Palmedo H, Otte R, Fimmers $R$, et al. Redifferentiation therapy-induced radioiodine uptake in thyroid cancer. J Nucl Med 1998;39:1903-6.

52. Schmutzler C, Köhrle J. Retinoic acid redifferentiation therapy for thyroid cancer. Thyroid 2000;10:393-405.

53. Simon D, Körber C, Krausch M, Segering J, Groth P, Görges $R$, et al. Clinical impact of retinoids in redifferentiation therapy of advanced thyroid cancer: final results of a pilot study. Eur J Nucl Med 2002;29:775-82.

54. Grüning T, Tiepolts C, Zöphel K, Bradow J, Kropp J, Franke W$G$. Retinoic acid for redifferentiation of thyroid cancer - does it hold its promise? Eur J Endocrinol 2003;148:395-402.

55. Coelho SM, Corbo R, Buescu A, Carvalho DP, Vaisman M. Retinoic acid in patients with radioiodine non-responsive thyroid carcinoma. J Endocrinol Invest 2004;27(4):334-9. 
56. Coelho SM, Vaisman M, Carvalho DP. Tumour re-differentiation effect of retinoic acid: a novel therapeutic approach for advanced thyroid cancer. Curr Pharm Des 2005;11(19):2525-31.

57. Monzani F, Caraccio N, Casolaro A, Lombardo F, Moscato G, Murri $L$, et al. Long-term interferon $\beta-1 b$ therapy for MS: is routine thyroid assessment always useful? Neurology 2000;22:549-52.

58. Rotondi M, Mazziotti G, Biondi B, Manganella G, Del Buono $A D$, Montella $P$, et al. Long-term treatment with interferonbeta therapy for multiple sclerosis and occurrence of Graves' disease. J Endocrinol Invest 2000;23(5):321-4

59. Durelli L, Ferrero B, Oggero A, Verdun E, Ghezzi A, Montanari $E$, et al. Thyroid function and autoimmunity during interferon $\beta-1 b$ treatment: a multicenter prospective study. J Clin Endocrinol Metab 2001:86(8):3525-32.

60. Caraccio N, Giannini R, Cuccato S, Faviana P, Berti P, Galleri $D$, et al. Type I interferons modulate the expression of thyroid peroxidase, sodium/iodide symporter, and thyroglobulin genes in primary human thyrocyte cultures. J Clin Endocrinol Metab 2005;90(2):1156-62.

61. Ajjan RA, Watson PF, Findlay C, Metcalfe RA, Crisp M, Ludgate $\mathrm{M}$, et al. The sodium iodide symporter gene and its regulation by cytokines found in autoimmunity. $J$ Endocrinol 1998;158(3):351-8

62. Spitzweg C, Joba W, Morris JC, Heufelder AE. Regulation of sodium iodide symporter gene expression in FRTL-5 rat thyroid cells. Thyroid 1999;9(8):821-30.

63. Grunstein M. Histone acetylation in chromatin structure and transcription. Nature 1997;25;389(6649):349-52.

64. Kuo $\mathrm{MH}$, Allis CD. Roles of histone acetyltransferases and deacetylases in gene regulation. Bioessays 1998;20(8):615-26.

65. Katan-Khaykovich Y, Struhl K. Dynamics of global histone acetylation and deacetylation in vivo: rapid restoration of normal histone acetylation status upon removal of activators and repressors. Genes Dev 2002;16(6):743-52.

66. Davie JR. MSK1 and MSK2 mediate mitogen- and stressinduced phosphorylation of histone H3: a controversy resolved. Sci STKE 2003;12(195):PE33.

67. Kitazono M, Robey R, Zhan Z, Sarlis NJ, Skarulis MC, Aikou $T$, et al. Low concentrations of the histone deacetylase inhibitor, depsipeptide (FR901228), increase expression of the $\mathrm{Na}^{+} / \mathrm{I}^{-}$symporter and iodine accumulation in poorly differentiated thyroid carcinoma cells. J Clin Endocrinol Metab 2001;86(7):3430-5.

68. Zarnegar $R$, Brunaud L, Kanauchi $H$, Wong $M$, Fung $M$, Ginzinger $D$, et al. Increasing the effectiveness of radioactive iodine therapy in the treatment of thyroid cancer using Trichostatin A, a histone deacetylase inhibitor. Surgery 2002;132(6):984-90.

69. Furuya F, Shimura H, Suzuki H, Taki K, Ohta K, Haraguchi K, et al. Histone deacetylase inhibitors restore radioiodide uptake and retention in poorly differentiated and anaplastic thyroid cancer cells by expression of the sodium/iodide symporter thyroperoxidase and thyroglobulin. Endocrinology 2004; 145(6):2865-75.

70. Fortunati N, Catalano MG, Arena K, Brignardello E, Piovesan A, Boccuzzi G. Valproic acid induces the expression of the $\mathrm{Na}^{+} / I^{-}$symporter and iodine uptake in poorly differentiated thyroid cancer cells. J Clin Endocrinol Metab 2004;89(2):1006-9.

71. Kitazono M, Chuman Y, Aikou T, Fojo T. Construction of gene therapy vectors targeting thyroid cells: enhancement of activity and specificity with histone deacetylase inhibitors and agents modulating the cyclic adenosine $3^{\prime}, 5^{\prime}$-monophosphate pathway and demonstration of activity in follicular and anaplastic thyroid carcinoma cells. J Clin Endocrinol Metab 2001:86(2):834-40.

72. Puppin C, D'Aurizio F, D'Elia AV, Cesaratto L, Tell G, Russo D, et al. Effects of histone acetylation on sodium iodide symporter promoter and expression of thyroid-specific transcription factors. Endocrinology 2005;146(9):3967-74.

73. Schmitt TL, Espinoza CR, Loos U. Transcriptional regulation of the human sodium/iodide symporter gene by Pax8 and TTF-1. Exp Clin Endocrinol Diabetes 2001;109(1):27-31.
74. Taki K, Kogai T, Kanamoto Y, Hershman JM, Brent GA. A thyroid-specific far-upstream enhancer in the human sodium/iodide symporter gene requires Pax-8 binding and cyclic adenosine $3^{\prime}, 5^{\prime}$-monophosphate response element-like sequence binding proteins for full activity and is differentially regulated in normal and thyroid cancer cells. Mol Endocrinol 2002;16(10):2266-82.

75. Puppin C, Presta I, D’Elia AV, Tell G, Arturi F, Russo D, et al. Functional interaction among thyroid-specific transcription factors: Pax8 regulates the activity of Hex promoter. Mol Cell Endocrinol 2004;214(1-2):117-25.

76. Fabbro D, Di Loreto C, Beltrami CA, Belfiore A, Di Lauro R Damante $G$. Expression of thyroid-specific transcription factors TTF-1 and PAX-8 in human thyroid neoplasms. Cancer Res 1994; $17: 4744-9$

77. Pasca di Magliano M, Di Lauro R, Tannini M. PAX8 has a key role in thyroid cell differentiation. Proc Natl Acad Sci USA 2000;221:13144-9.

78. Presta I, Arturi F, Ferretti E, Mattei T, Scarpelli D, Tosi E, et al. Recovery of NIS expression in thyroid cancer cells by overexpression of Pax8 gene. BMC Cancer 2005;5(1):80.

79. Suzuki K, Lavaroni S, Mori A, Ohta M, Saito J, Pietrarelli M, et al. Autoregulation of thyroid-specific gene transcription by thyroglobulin. Proc Natl Acad Sci USA 1998;95(14):82516.

80. Dohan O, De la Vieja A, Carrasco N. Hydrocortisone and purinergic signaling stimulate sodium/iodide symporter (NIS)-mediated iodide transport in breast cancer cells. Mol Endocrinol 2006;20(5):1121-37.

81. De La Vieja A, Ginter CS, Carrasco N. The Q267E mutation in the sodium/iodide symporter (NIS) causes congenital iodide transport defect (ITD) by decreasing the NIS turnover number. J Cell Sci 2004:117(Pt 5):677-87.

82. De la Vieja A, Ginter CS, Carrasco N. Molecular analysis of a congenital iodide transport defect: G543E impairs maturation and trafficking of the $\mathrm{Na}^{+} / /^{-}$symporter. Mol Endocrinol 2005;19(11):2847-58.

83. Trouttet-Masson S, Selmi-Ruby S, Bernier-Valentin F, Porra $V$, Berger-Dutrieux N, Decaussin M, et al. Evidence for transcriptional and posttranscriptional alterations of the sodium/iodide symporter expression in hypofunctioning benign and malignant thyroid tumors. Am J Pathol 2004:165(1):25-34.

84. Mian C, Lacroix L, Alzieu L, Nocera M, Talbot M, Bidart JM, et al. Sodium iodide symporter and pendrin expression in human thyroid tissues. Thyroid 2001;11(9):825-30.

85. Mazzaferri EL, Jhiang SM. Long-term impact of initial surgical and medical therapy on papillary and follicular thyroid cancer. Am J Med 1994;97(5):418-28.

86. Ryu KY, Senokozlieff ME, Smanik PA, Wong MG, Siperstein $A E$, Duh QY, et al. Development of reverse transcription-competitive polymerase chain reaction method to quantitate the expression levels of human sodium iodide symporter. Thyroid 1999:9(4):405-9.

87. Jhiang SM, Cho JY, Ryu KY, DeYoung BR, Smanik PA, McGaughy VR, et al. An immunohistochemical study of $\mathrm{Na}^{+} / /^{-}$symporter in human thyroid tissues and salivary gland tissues. Endocrinology 1998;139(10):4416-9.

88. Arturi F, Russo D, Schlumberger M, du Villard JA, Caillou B, Vigneri $P$, et al. lodide symporter gene expression in human thyroid tumors. J Clin Endocrinol Metab 1998;83(7):24936.

89. Dohan O, Carrasco N. Thyroidal iodide transport and thyroid cancer. Cancer Treat Res 2004:122:221-36.

90. Cho JY. A transporter gene (sodium iodide symporter) for dual purposes in gene therapy: imaging and therapy. Curr Gene Ther 2002;2(4):393-402.

91. Mandell RB, Mandell LZ, Link CJ Jr. Radioisotope concentrator gene therapy using the sodium/iodide symporter gene. Cancer Res 1999;59(3):661-8.

92. Cho JY, Xing S, Liu X, Buckwalter TL, Hwa L, Sferra TJ, et al. Expression and activity of human $\mathrm{Na}^{+} / \mathrm{I}^{-}$symporter in human glioma cells by adenovirus-mediated gene delivery. Gene Ther 2000;7(9):740-9. 
93. Elisei R, Vivaldi A, Ciampi R, Faviana P, Basolo F, Santini F, et al. Treatment with drugs able to reduce iodine efflux significantly increases the intracellular retention time in thyroid cancer cells stably transfected with sodium iodide symporter complementary deoxyribonucleic acid. J Clin Endocrinol Metab 2006;91(6):2389-95.

94. Kakinuma H, Bergert ER, Spitzweg C, Cheville JC, Lieber MM, Morris JC. Probasin promoter (ARR(2)PB)-driven, prostatespecific expression of the human sodium iodide symporter (h-NIS) for targeted radioiodine therapy of prostate cancer. Cancer Res 2003;63(22):7840-4.

95. Spitzweg C, Morris JC. Gene therapy for thyroid cancer: current status and future prospects. Thyroid 2004;14(6):424-34.

96. Spitzweg C, Dietz AB, O'Connor MK, Bergert ER, Tindall DJ, Young $C Y$, et al. In vivo sodium iodide symporter gene therapy of prostate cancer. Gene Ther 2001;8(20):1524-31.

97. Cengic N, Baker CH, Schutz M, Goke B, Morris JC, Spitzweg C. A novel therapeutic strategy for medullary thyroid cancer based on radioiodine therapy following tissue-specific sodium iodide symporter gene expression. J Clin Endocrinol Metab 2005;90(8):4457-64

98. Dingli D, Kemp BJ, O'Connor MK, Morris JC, Russell SJ, Lowe VJ. Combined ${ }^{124}$ | positron emission tomography/computed tomography imaging of NIS gene expression in animal models of stably transfected and intravenously transfected tumor. Mol Imaging Biol 2006;8(1):16-23.

99. Zuckier LS, Dohan O, Li Y, Chang CJ, Carrasco N, Dadachova E. Kinetics of perrhenate uptake and comparative biodistribution of perrhenate, pertechnetate, and iodide by $\mathrm{Na} / \mathrm{l}$ symporter-expressing tissues in vivo. J Nucl Med 2004;45(3):500-7.
100.Dadachova E, Nguyen A, Lin EY, Gnatovskiy L, Lu P, Pollard JW. Treatment with rhenium-188-perrhenate and iodine-131 of NIS-expressing mammary cancer in a mouse model remarkably inhibited tumor growth. Nucl Med Biol 2005;32(7):695-700.

101.Dadachova E, Bouzahzah B, Zuckier LS, Pestell RG. Rhenium188 as an alternative to lodine-131 for treatment of breast tumors expressing the sodium/iodide symporter (NIS). Nucl Med Biol 2002;29(1):13-8.

102.Petrich T, Helmeke HJ, Meyer GJ, Knapp WH, Potter E. Establishment of radioactive astatine and iodine uptake in cancer cell lines expressing the human sodium/iodide symporter. Eur J Nucl Med Mol Imaging 2002;29(7):842-54.

\section{Address for correspondence:}

Denise P. Carvalho

Instituto de Biofísica Carlos Chagas Filho

Avenida Carlos Chagas Filho s/n, CCS, Bloco $G$

Cidade Universitária, Ilha do Fundão

21941-902 Rio de Janeiro, RJ

Fax: (21) 2280-8193

E-mail: dencarv@biof.ufrj.br 